\title{
Understanding the Issues of Waqf at Public University: Preliminary Findings
}

\author{
NORLAILA MAZURA HJ. MOHAIYADIN* \& AINI AMAN
}

\section{ABSTRACT}

\begin{abstract}
There are limited empirical studies on waqf management, especially in public university. Some studies highlighted the issues of accountability and transparency in managing the collection and distribution of waqf system that require further study. Using institutional logic, this study hopes to provide further understanding on the challenges faced by public university in managing waqf. This study uses qualitative research with a case study approach on a public university in Malaysia. Data collection covers interviews with stakeholders and document reviews. Preliminary findings show that there are some challenges in the accountability and transparency of waqf collection and distribution faced by public university. Theoretically, this study extends the understanding on the issues of accountability and transparency, particularly in waqf management. This study also recommends the best practices of waqf management for public university.
\end{abstract}

Keywords: accountability, transparency, waqf, public university, institutional logic

The appointment of public university as a Nazir or Mutawalli or Qayyim (Waqf Administrator) is monitored by the State Islamic Religious Council, and is requested to take a thrifty, thorough, and careful attitude, so that each waqf property can be developed in the best way possible to ensure that the property lasts for socio-economics of Muslims as stated by JAWHAR (2018). Waqf funds should be managed efficiently with good governance by addressing accountability and transparency challenges among public universities as waqf administrator works best on behalf of Allah g.t.h. to fellow human beings or stakeholders as stated by JAWHAR (2018). Thus, the researchers believe that this will contribute to the challenges faced by public university in managing waqf, especially in terms of accountability and transparency.

There are limited empirical studies on waqf management, particularly ones that focus on public university. Available empirical studies on waqf carried out for the State Islamic Religious Council in Malaysia include Siraj (2012), Habidin et. al. (2017), Hairul Suhaimi et. al. (2018), Arshad et. al. (2018), Abu Talib et. al. (2018), and Abu Talib et. al. (2020); religious schools, boarding schools, and religious-based madrasah, such as Taib et. al. (2016) and Saidon, Mat Rani, Muhamad, \& Ishak (2019). Furthermore, according to Taib et. al. (2016) and Syakir, Taib, Mujani, Rozali \& Khalid (2017), the issue of waqf in public university is still unreliable and impractical in Malaysia, and the discussion is also limited to non-empirical studies, such as Abdul Razak et. al. (2016); Omar et. al. (2016); and Suhaili (2016). Non-empirical means that the research is not based on observations, experiments, and inferred data as stated by Walker \& Moore (1997). Besides that, Ali \& Wahid (2014) reported that the performance of waqf funds among public universities in Malaysia is indeed different and does not guarantee higher collection. They also suggested that investments with large returns to be made for waqf funds received or at least deposited into a fixed savings account with the concept of Mudharabah. Ahmad et. al. (2016) reported that one of the issues in managing waqf funds in public university is collection and

1 Norlaila Mazura Hj. Mohaiyadin*(Corresponding Author), Ph.D. candidate, Faculty of Economics and Management, Universiti Kebangsaan Malaysia, BangI, MALAYSIA. Email: norlaila@upnm.edu.my; Aini Aman, Ph. D., Professor at Faculty of Economics and Management, Universiti Kebangsaan Malaysia, Bangi, MALAYSIA. Email: aini@ukm.edu.my 
distribution of waqf funds. On the other hand, Johan et. al. (2016) highlighted that one of the challenges faced by public university in managing waqf is transparency, whereas Hussin \& Abdul Rashid (2017) reported that working with stakeholders is one of the improvements made in managing waqf funds in public university

Furthermore, some studies highlight the issues of accountability and transparency in managing the collection and distribution of waqf system that require further scrutiny. AbdulRahman \& Goddard (1998) stated that there is no improvement in terms of accountability in two State Islamic Religious Councils in Malaysia. Afifuddin \& Siti-Nabiha (2010) also claimed that there are incompetent management scandals, and the illegal use of waqf funds raised questions about the governance and accountability of waqf institutions. However, they also mentioned that those studies are far limited. Besides that, in reference to issues of waqf fund collection and distribution management as discussed by Babacan (2011), and database and record issues reported by Ghazali \& Md. Sawari (2014), it is shown that such issues enable elements of distrust, untruth, and injustice in the financial reporting of waqf funds. Researchers found that there are studies on accountability and transparency, but they are focused on State Islamic Religious Councils in Malaysia, such as Siraj (2012) and Habidin et. al. (2017), and on international councils, such as Ihsan \& Hj. Mohamed Ibrahim (2011) and Siswantoro et. al. (2018) in Indonesia and Alomair (2018) in the United Arab Emirates. However, empirical studies on accountability in waqf only show how the waqf institution discharges accountability, but not how they overcome those challenges.

Using institutional logic, this study aims to provide further understanding on the challenges faced by public universities in managing waqf, especially in terms of accountability and transparency. The research questions formulated are: (1) what are the challenges faced by public university in waqf management? and (2) how could blockchain enhance accountability and transparency in waqf management? This study could contribute to further understanding on how blockchain technology solves the challenges of accountability and transparency in waqf management, and increases the trust of stakeholders, including customers, suppliers, the government, and regulatory agencies.

\section{Literature Review}

Literature review serves a role in identifying the background of existing issues and providing upto-date information on the field under study. This literature review includes reviews on basic concepts of waqf implementation in public university, accountability and transparency challenges in implementing waqf, accounting information system for waqf institutions, and institutional theory and institutional logic to underpin this study. This section begins with the reviews on basic concepts of waqf implementation in Malaysian public university as presented in the following section.

\section{Basic Concepts of Waqf Implementation in Malaysian Public University}

There are three basic concepts of waqf implementation in public universities as described by KPTM (2016), these include waqf giver or Al-Waqif, waqf administrator or Mutawalli, and beneficiary or Mauquf Alaihi. Al-Waqif is the party who voluntarily grants legally owned assets or Al-Mauquf that moves or does not move for a specific purpose or Niyyah to benefit others or Mauquf Alaihi and to show his obedience to Allah g.t.h. through good deeds (KPTM, 2016). According to KPTM (2016), the sole trustee of waqf or Mutawalli for Malaysian public university refers to the State Islamic Religious Council (SIRC) in their respective states, and Malaysian public university must obtain permission from SIRC to become a waqf administrator or obtain the status as a Nazir or Mutawalli or Qayyim. As the waqf administrator, the public university is authorised by SIRC to collect, use, manage, invest, develop, and distribute Waqf returns based on the Memorandum of Agreement between SIRC and the public university (KPTM 2016). Public university must use all expertise, tools, and strategies to ensure the growth of waqf Shariah 
compliance (KPTM, 2016). The waqf returns will be distributed to beneficiaries or Mauquf Alaihi to Muslim or non-Muslim students in the form of scholarships, research grants, and so on (KPTM, 2016).

Habidin et. al. (2017) mentioned that the waqf system can be considered good when there are accountability and transparency of the waqf institution. Mansor \& Jamil (2018) proposed a new proactive reporting for waqf reporting known as integrated waqf reporting system and elaborated that this system increases the financial reporting accountability of the waqf fund. The World Bank Group (2019) also claimed that there is no regulatory framework to ensure transparency and integrity of waqf financial fundraising, but due to the existence of a digital economy to address issues of transparency and trust; this includes the use of digital wallet applications or e-wallets, and blockchain technology. Azganin (2019) suggested that there is empirical evidence on the application of blockchain technology in waqf institutions in waqf fund raising and waqf land, increasing transparency.

\section{Accountability and Transparency Challenges in implementing Waqf}

Ihsan \& Hj. Mohamed Ibrahim (2011) studied on accounting, management practices, and sought evidence on how to implement accountability using in-depth interview in two Mutawallis, Indonesia. Ihsan \& Hj. Mohamed Ibrahim (2011) found that the management of Mutawalli ABC is managed by the Waqf Division, and it has employees working full time with free waqf asset facilities, but Mutawalli XYZ has employees working part time with no free waqf asset facilities. The dissemination of reporting for Mutawalli ABC is widespread, but the dissemination of reporting for Mutawalli XYZ is not (Ihsan \& Hj. Mohamed Ibrahim 2011). This indicates that there are differences in terms of accountability mechanisms by the two Mutawallis.

Siraj (2012) studied on the accounting, accountability, and effectiveness of waqf management in the State Islamic Religious Council (SIRCs), Malaysia. In terms of autonomy and accountability, Siraj (2012) proposed that SIRCs should be more flexible, have greater autonomy, less disturbed by government decisions, and be more collective. In terms of strategic planning, Siraj (2012) admitted that only a few Chief Executive Officers implement strategic planning and that there are limited involvement by outsiders, no specific guidelines, and relatively strict estimation and control practices. In terms of performance measurement practices, Siraj (2012) reported that there were difficulties in measuring related costs and financial reporting practices. Siraj (2012) also commented on the use of external consultants, cooperation, and privatisation plans for the waqf accounting system, but details on how the waqf accounting system for SIRCs operates are still in question (also reported by Hairul Suhaimi et. al. (2018)). This also applies to public university that serve as waqf administrator. Therefore, the researchers are interested to investigate further on the waqf system of a public university, which also lacks researches.

Masruki \& Shafii (2013) assessed the need to develop accounting standards and the recommended Practice Framework for Accounting and Financial Auditing for Mutawalli or SIRCs in Malaysia, and reported that the federal government plays a primary role to increase Mutawalli's transparency and accountability. Masruki \& Shafii (2013) also added the benefits of the development of waqf accounting and the absence of accounting guidelines and standards, which result to the lack of accountability and transparency. The issue of guidelines and accounting standards for waqf should be accounted to the government as the determinant of waqf management. Furthermore, development of accounting standards also includes the accounting system (also reported by Hairul Suhaimi et. al. (2018)), but Masruki \& Shafii (2013) only focused on accounting standards.

Ihsan \& Septriani (2016) found evidence based on a literature review on how accountability in Awqaf (compound words for waqf) should be practised and reported disclosure (also reported by Haneef (2016)), performance appraisal and evaluation, participation, selfregulation, and social audit. Stakeholders, such as Al-Waqif, clients, and beneficiaries have access to financial information through disclosure statements and reports; performance appraisal is 
very important for internal and external Accountability; involves four levels of participation (public hearing, public engagement, public decision making, and public initiative); conducted by the government or regulators (normative views) for self-regulation and social audit through dialogue with the Stakeholders (Ihsan \& Septriani 2016).

Alomair (2018) evaluated and compared the governance and accountability practices of the three waqf institutions in Saudi Arabia, and found that the internal governance mechanisms were in terms of waqf registration and waqf practices, flexibility and control; stakeholders for waqf include Al-Waqif, beneficiaries, courts, governments, and the community. Siswantoro et. al. (2018) studied on cash waqf accountability in Indonesia and found that there are unique and different logical approaches to accountability in terms of control and conflict, elite, government assessment, purpose, and limitations of accountability, as well as Shariah compliance, and audit. Furthermore, Abu Talib et. al. (2020) discussed the challenges in the use of waqf accounting and reporting, but this discussion is related to accountability and transparency. For example, Abu Talib et. al. (2020) reported that the submission of current reporting is made to the council for each year of accounting period.

\section{Accounting Information System for Waqf Institutions}

Information system management is considered successful when taking into account three perspectives, which refer to the perspective of people or actor, perspective of process, and perspective of technology as stated by Barney et. al. (2008), Zhang et. al. (2013), and Haron et. al. (2013). The perspective of people or actor is related to the perspective of the stakeholders in the information system as stated by Zhang et. al. (2013) and Haron et. al. (2013), and how they play a role as a participant or node in the blockchain technology network as reported by Nurul et. al. (2018) and Singh et. al. (2019). Ihsan (2007), Alomair (2018), and Hamdan et. al. (2019) reported that the Mutawalli has greater accountability and transparency to the stakeholders, such as Al-Waqif, waqf board, government, beneficiaries or Mauquf Alaihi, and society, but there is no further discussion on how the Mutawalli involves them in the waqf decision-making or waqf system.

In the perspective of process, researchers found that previous studies on input-processoutput were on SIRCs and corporate waqf only, but not on input-process-output for public university waqf due to the limited researches in this field. However, researchers took previous studies from Nahar \& Yaacob (2011) and Iman \& Mohammad (2017) as a guide for this study. This is because the study from Nahar \& Yaacob (2011) focused on accounting information systems from input and process to output. Input refers to collection, process refers to activity, and output refers to distribution. The input-process-output practice formulated by Iman \& Mohammad (2017) is similar to Nahar \& Yaacob (2011), but the focus given to the distribution of waqf funds (return from the waqf fund investments) that have been invested because the waqf fund needs to maintain its' Ain or physical form as stated by JAWHAR (2008).

Siti Umairah \& Siti Mashitoh (2016) reported that the waqf project under one of the public universities in Malaysia obtained contributions from individuals and corporate companies, and made contribution in the form of investment maintained either in the form of building or cash investment according to Shariah. The construction of this building is able to increase the income of the university through the rental of business sites and the rental proceeds are used for qualified student scholarships (Siti Umairah \& Siti Mashitoh 2016). In addition, Siti Umairah \& Siti Mashitoh (2016) also reported that only the Waqf IIm, Public University A has a representative from the State Islamic Religious Council to determine the waqf distribution.

Researchers found that there are three legal issues and the recognition of assets, income, and expenses here; (1) ownership of a waqf asset using waqf funds, whether the waqf asset is owned by SIRC or public university even if the acquisition of the waqf fund is undertaken by the public university, (2) revenue and expenditure usage decisions, such as repairs will be the result of the SIRC or public university or there are certain ratios shared, and (3) management of sale and exchange of waqf or Istibdal, whether the public university obtains permission or not from 
the SIRC to manage. These three issues are related to the State Enactment and indirectly, the challenges of accountability and transparency also exist, especially to the SIRC. This matter was also stated by KPTM (2016), which reported that one of the challenges to implement waqf for public university refers to legal restrictions that require permission from the SIRC.

From the perspective of technology, Zulaikha \& Arif Rusmita (2018) developed a conceptual framework for waqf management using blockchain technology in Indonesia and have identified the stakeholders for waqf institutions in Indonesia involved in the waqf system using blockchain technology, which includes the government, waqf institutions, waqf banks, waqf assessors, beneficiaries, Al-Waqif, and related institutions. Zulaikha \& Arif Rusmita (2018) also reported that blockchain technology can be used in the waqf system as a tool to raise funds from abroad and prove transparency. However, this study by Zulaikha \& Arif Rusmita (2018) does not focus on which waqf institution. suggested that The Finterra Waqf Chain under his study but the findings are limited to the non-empirical findings, same goes to study by Gazali \& Che Ismail (2019).

\section{Institutional Theory and Institutional Logic}

This study develops a theory based on the challenges faced by public university in managing waqf, especially on accountability and transparency, drawing on the work of DiMaggio \& Powell (1983) in institutional theory, and Friedland \& Alford (1991) in institutional logic. Institutional theory has three elements of isomorphism (homogenisation) pressure, which refer to coercive element resulting from political pressure and legitimacy problems; normative element associated with professional body pressure; and mimetic element related to other organisational pressures that are more successful to follow the performance, structure, and practices of other organisations (DiMaggio \& Powell, 1983). However, Meyer et. al. (1977) criticised the isomorphism because social relationships are limited to individual and organisational initiatives, whereas institutional logic encompasses organisational and cultural material practices as highlighted by Thornton \& Ocasio (1999). Therefore, to close the research gaps, researchers in this study decided to extend institutional theory with institutional logic as proposed by Lounsbury (2008), who stated that accounting studies have used Information Technology to address institutional uniformity or homogeneity and organised the study of institutional diversity or heterogeneity or institutional logic.

Researchers identified four logics related to this study; socio-technical system, stakeholder, multiple accountability and transparency, and Islamic accountability and transparency. Researchers found that Geels (2004) and Williams et. al. (2013) proved that the socio-technical system has existed in the Coercive element; Geels (2004), Williams et. al. (2013), and Fuenfschilling \& Truffer (2014) found that the socio-technical system has existed in the normative element; and only Fuenfschilling \& Truffer (2014) found that the socio-technical system has existed in the mimetic element. However, researchers revealed that there is no further discussion on the socio and technical segregation in socio-technical that exists in the institutional theory so far. Furthermore, Brignall \& Modell (2000), Parent et. al. (2015), and Alomair (2018) also found that the stakeholder logic has existed in the coercive element; Brignall \& Modell (2000) and Parent et. al. (2015) found that the stakeholder logic has existed in the normative element; and only Parent et. al. (2015) found that the stakeholder logic exists in the mimetic element. However, researchers are in the opinion that stakeholder logic can only exist in the coercive element to demonstrate accountability and transparency to the stakeholders.

Only Gálvez Rodríguez et. al. (2012) and Rana \& Hoque (2020) found that the multiple accountability and transparency logic exist in the coercive element; Sanzo-Pérez et. al. (2017) and Rana \& Hoque (2020) found that the multiple accountability and transparency logic has existed in the normative element; and only Sanzo-Pérez et. al. (2017) prove that transparency logic has existed in the mimetic element. The discussion on multiple accountability and transparency logic is also linked to the Islamic accountability and transparency logic. Researchers found that Alomair (2018) and Abu Talib et. al. (2020) prove that the Islamic accountability and transparency logic 
has existed in the normative element and Abu Talib et. al. (2020) prove that the Islamic accountability and transparency logic has existed in both the coercive element and the mimetic element.

\section{Research Methodology}

This study uses qualitative research with a case study approach of a public university in Malaysia and more precisely, an interpretive case study, drawing on the work of Walsham (1995) and Vaast \& Walsham (2005) in the study of information systems. According to Walsham (1995) and Vaast \& Walsham (2005), interpretive case study is implemented for three purposes; 1) as a preliminary guide for research design and data collection, 2) as part of the iterative processes for data collection and data analysis, and 3) as a guide to produce the final product of the research, which refers to the theoretical framework. In addition, interpretive case study has a lot of data to study in depth about the content and meaning of institutional logic in this study because it requires a "thick description" from the participants as stated by Walsham (1995) and Yin (2003).

Data collection covers interviews with stakeholders and document reviews. Walsham (1995) stated that interviews are an excellent source of data because researchers can access the best interpretations from participants who know about the actions and situations that have been or are happening at the sampling location. Researchers use the Interview Protocol Refinement Framework inspired by Castillo-Montoya (2016) to develop the interview protocol in a semistructured format inspired by O'Donoghue (2006). There are five parts in the interview protocol in this study; Part 1 is provided for public university's waqf practitioners featuring 11 semistructured questions based on institutional theory and institutional logic, Part 2 is prepared for public university's waqf beneficiaries featuring four semi-structured questions based on institutional theory and institutional logic, Part 3 focuses on public university's waqf givers or $\mathrm{Al}$ Waqif and SIRC's representative who dealt with public university's waqf unit four semistructured questions based on institutional theory and institutional logic, Part 4 is provided for Shariah experts featuring two semi-structured questions based on institutional theory and institutional logic, and Part 5 is provided for blockchain technology experts featuring three semistructured questions based on institutional theory and institutional logic.

However, due to interpretive case study involving iterative processes for data collection and data analysis as mentioned by Walsham (1995) and Vaast \& Walsham (2005) and to fulfil the purpose of this preliminary study, the researchers managed to obtain a participant, Director of Endowment Unit, in one of the public universities in Malaysia using purposive sampling technique, which aims to select specific units to produce the most relevant and rich data as proposed by Yin (2011). This interview was initially scheduled between 30 and 60 minutes as suggested by O'Donoghue (2006), but lasted up to two hours and this interview was recorded using voice recorder in two languages (Malay and English), transcribed, and translated.

This interview sought to understand the challenges faced by public university in managing waqf, especially on accountability and transparency. A research note was taken during the interview to record interpretations made when assembling the findings. O'Donoghue (2006) and Creswell \& Creswell (2018) mentioned that document reviews are another reliable way to collect data for semi-structured interview and therefore, the researchers arranged for the permitted handouts from participants, materials from public university's web sites, and press release. The researchers also used data analysis by Orlikowski (1993), Walsham (1995), and Strauss \& Corbin (1998). Walsham (1995) stated that data analysis involved iterative process between field data and theory; it takes place and evolves over time, and the researchers will adopt the same process for the actual research later. Theory here refers to institutional theory with institutional logic. Subsequently, all data will be analysed using open coding, axial coding (Strauss \& Corbin 1998), and re-coded (Orlikowski 1993). 


\section{Preliminary Findings and Discussion}

Preliminary findings demonstrate that there are some challenges in the accountability and transparency of waqf collection and distribution faced by public university using institutional logic. Researchers have identified three logics related to this study; socio-technical system, stakeholder, and Islamic accountability and transparency. Discussions on how institutional logic underpinning the preliminary findings of this study is presented in the following section.

\section{Unpleasant perceptions by Other Units or Beneficiaries}

Geels (2004) reported that the regulative or coercive element refers to the system used, which must be through legally binding contracts, technical standards, and government regulations. Researchers found that the elements of socio from socio-technical system logic in public university's waqf system exist in the coercive element of institutional theory based on the preliminary finding as follows:

\footnotetext{
"The process is disconnecting between collection and distribution - that's right because it is a decision from another unit, such as the Health Centre...but you have to report back, especially if there is a question from the auditor or make a special report..."
}

Public university's waqf system should also include other units directly involved in the waqf distribution (output) so that there is no process disruption between collection (input) and distribution (output) in the system. Nahar \& Yaacob (2011) stated that waqf accounting information system covers from input to output. It seems that existing public university's waqf system does not involve many parties or better known as stakeholders between collection (input) and distribution (output), especially for waqf project and researchers agreed that this is one of the transparency challenges faced by public university's waqf system.

In relation to the justification of socio element from socio-technical system logic, stakeholder logic can exist in the coercive element of institutional theory. This is in line with Brignall \& Modell (2000), Parent et. al. (2015), and Alomair (2018). Based on the following preliminary findings, it shows that the employees involved with RM1 Waqf campaign are the stakeholders of the waqf system:

"... The RM1 Waqf campaign was also made through salary deductions ..."

Besides that, researchers also found that the public university's waqf system faces transparency challenges when there are unpleasant perceptions by other units or beneficiaries in public university that do not understand the real function of Waqf and have their own interests based on the following preliminary findings:

"...About the yield...people will talk about why they are in the Endowment Unit; other units want to use it, too..."

\section{Uncertainty in Distribution}

This section relates to the justification of the stakeholder logic, which can exist in the coercive element of institutional theory. Researchers agreed that Al-Waqif should be involved in the public university's waqf system to avoid any wastes of waqf fund or uncertainty in distribution of student scholarship from two different institutions and to not violate the policies set by the Public University in relation to student scholarships (Mauquf Alaihi). This interpretation is based on the preliminary finding as follows: 
“...The problem is when a student gets more than one scholarship, the student does not let us know that he gets sponsorship from another party until the other party informs us...In university's policy, our students cannot receive more than one scholarship..."

\section{Possibility of Entry Error}

Researchers found that the technical element (process) from socio-technical system logic has existed in the normative element of institutional theory. The Normative element refers to social and organisational networks reinforced by shared role perceptions and correct behavioural expectations, where such relationships do not raise specific issues and assume that customers are more interested in consistent product quality than the performance environment (Geels, 2004). In the normative element, Williams et. al. (2013) found that the professional framework can shape system structural changes in various contexts to consider the views of various parties. However, researchers found that the accountability challenge also exists in the public university's waqf system based on the following preliminary findings:

"Only one entry money has no declaration of name, only 'Servant of Allah' (Hamba Allah) ...that entry has been for a long time and sometimes asks for a receipt and the Auditor accepts this matter..."

Although the auditor accepts this, this is a reference to the accountability challenges faced and concerns over the possibility of entry error in the receipt for the 'Servant of Allah' which has no record tracking or no historical background that could lead to the issuance of a receipt to the wrong Al-Waqif. This matter needs to be addressed because Al-Waqif can claim a deduction under Subsection 44 (1D) of the Income Tax Act, which requires complete details of Al-Waqif as stated by LHDN (2020) and to avoid issuance of incorrect nominee receipts.

\section{Unpleasant perceptions on Blockchain technology}

Researchers found that the technical element (technology) from socio-technical system logic has existed in the normative element of institutional theory in the public university's waqf system. Fuenfschilling \& Truffer (2014) stated that system structure has become normative when no system design changes occur, system failure is relatively low, resistance is relatively low from the stakeholders, and the function of the system is not questioned until there are unpleasant perceptions of the blockchain technology proposed by the researchers based on the following preliminary findings:

"... This blockchain is a little messy...for example...my unit receives RM2,500 and will remain there...loss if not invest...can blockchain solve this problem?"

Researchers agreed that the above situation is related to the conflict of interest of public university and accountability challenges may occur to stakeholders. Based on Deloitte (2020) reports, many organisations are aware that blockchain can cope with accountability challenges related to customers, suppliers, investors, government, and regulatory agencies. Apart from that, participant also agreed that this blockchain technology has a conflict between technology and law based on the following preliminary findings:

“... That is the problem of blockchain wanting to know to reach at the end...waqf must remain at Principal...and apply only to investment yield to be used to Mauquf Alaihi... The weakness of blockchain is that it has to be used up while Section 44 (6) of Income Tax Act must apply at least $50 \% \ldots "$ 


\section{Unstandardisation on Istibdal decisions}

Researchers found that there are only two waqf studies, Alomair (2018) and Abu Talib et. al. (2020) who use institutional theory to support their study. In terms of the implementation of the accountability mechanisms, questions on accountability for what?, accountability for how? Alomair (2018) used recommendations by Cutt \& Murray (2003) and Ebrahim (2003). Researchers agreed that this matter is related to the professional responsibility of the organisation to perform a job according to the standards or laws or procedures that have been used. Thus, the normative element exists in Islamic accountability.

Besides that, researchers also argued that the extension of findings from Abu Talib et. al. (2020) on accountability to Allah g.t.h. or Hablun Min Allah needs to be extended to accountability to human being or Hablun Min An-Nas. This has also been described by Abdul Rahman (2003), Abu-Tapanjeh (2009), Ihsan \& Adnan (2009), Ramli et. al. (2014), and Basri et. al. (2016). In addition, accountability to Allah g.t.h. by Abu Talib et. al. (2020) should be extended with Maghfirah and Barokah (investment); referring to fixed deposit investment and avoid investing in investments that violate the waqf principles that exist in the normative element. However, researchers found that there is a challenge of accountability and transparency on Istibdal (sale and exchange of waqf property) which refers to the conversion of waqf fund (cash) into a building based on the following preliminary findings:

“...The Rector gets waqf funds to make commercial properties...the proceeds are included in scholarships and operating costs because in the Enactment, it is recognised as Waqf IIm...There is a Shariah Council chaired by lecturers of the Faculty of Law and has reached $L P U . . . "$

"...Waqf Land through Waqf Ilm - Al-Waqif provides cash and we build buildings; people know and the land is the property of the university under MOHE..."

Based on the above preliminary findings, the decision on Istibdal (sale and exchange of waqf property) seems to involve the internal committee of the institution only, not involving the Fatwa Committee and SIRC representatives, and the ownership of the building has also become an issue in public university under the Ministry of Higher Education. This shows that the absence of the standards or norms on the decision or unstandardisation on Istibdal decisions among public universities in Malaysia, such as Siti Umairah \& Siti Mashitoh (2016) have reported that only the Waqf IIm, Public University A has a representative from the State Islamic Religious Council to determine the waqf distribution.

Apart from that, Istibdal is also related to Enactment, such as Enactment 15, Waqf Enactment (State of Selangor) 2015, Section 4 (2), which stated that any manager or administrator appointed under paragraphs (b) and (c) shall have the duties and responsibilities as prescribed by the Majlis (Selangor 2015). KPTM (2016) also reported that one of the challenges in implementing waqf in public university refers to the legal restrictions of the term waqf, which requires permission from SIRC and is considered an obstacle although it is a regulatory requirement.

\section{Implications and Future Study}

Theoretically, this study extends the understanding on the issues of accountability and transparency, particularly in waqf management. This study contributes to the integration between waqf system and technology studies and Islamic studies. This study proves that Islam is a good guide in managing all areas due to obedience to Allah g.t.h. and loving others through the improvement of accountability and transparency challenges found in the public university's waqf system. This study also contributes to the extension of institutional theory by DiMaggio \& Powell (1983) with institutional logic (Friedland \& Alford 1991). Institutional logics here refer to sociotechnical system logic, stakeholder logic, and Islamic accountability and transparency logic. Researchers highlighted that Abu Talib et. al. (2020) introduced Islamic religion logic in the study 
of accounting and reporting of waqf for SIRC, and this study extends the religion logic with Islamic accountability and transparency logic. This study supports the interpretive case study by Walsham (1995) who introduced it in the field of information systems research.

Practically, this study suggests the best practices of waqf management in public university. Researchers intend to introduce the development of the blockchain technology framework to improve the public university's waqf system in Malaysia. Given the many benefits of blockchain technology in addressing the challenges of accountability and transparency in both financial and non-financial systems as reported by Linn \& Koo (2016), Zulaikha \& Arif Rusmita (2018), and Deloitte (2020), the researchers agreed that blockchain technology may improve existing public university's waqf system. Since waqf is a trust from the public and the trust given to the waqf institution to manage, waqf administrators (public university) must act with full accountability and transparency to manage Waqf and should not be neglected. This is because the public university's waqf unit also carries two accountabilities, namely accountability to Allah g.t.h. and accountability to human being, which is referring to the stakeholder's identification through coercive element of institutional theory in this study.

\section{Acknowledgement}

This is to acknowledge UKM research grant EP-2020-016 for financial assistance.

\section{References}

Abdul-Rahman, A. R. \& Goddard, A. 1998. An interpretive inquiry of accounting practices in religious organisations. Financial Accountability and Management. 14(3): 183-201. doi:10.1111/1468-0408.00060

Abdul Rahman, A. R. 2003. Accounting regulatory issues on investments in Islamic bonds. International Journal of Islamic Financial Services. 4(4): 1-11.

Abdul Razak, D., Che Embi, N. A., Salleh, M. C. M. \& Fakhrunnas, F. 2016. A study on sources of waqf funds for higher education in selected countries. Adam Akademi. 6(1): 113-128.

Abu-Tapanjeh, A. M. 2009. Corporate governance from the Islamic perspective: A comparative analysis with OECD principles. Critical Perspectives on Accounting. 20(5): 556-567. doi:10.1016/j.cpa.2007.12.004

Abu Talib, N. Y., Abdul Latiff, R. \& Aman, A. 2020. An institutional perspective for research in waqf accounting and reporting: A case study of Terengganu state Islamic Religious Council in Malaysia. Journal of Islamic Accounting and Business Research. 11(2): 400-427. doi:10.1108/JIABR-11-2016-0132

Abu Talib, N. Y., Abdul Latiff, R., Aman, A. \& Palil, M. R. 2018. An exploratory study of accounting and reporting practice for waqf among state Islamic Religious Councils in Malaysia. International Journal of Islamic Thought. 13(1): 90-105. doi:10.24035/ijit.06.2018.009

Afifuddin, H. B. \& Siti-Nabiha, A. . 2010. Towards good accountability: the role of accounting in islamic religious organisations. International Journal of Social, Behavioral, Educational, Economic, Business and Industrial Engineering. 4(6): 1141-1147.

Ahmad, Z., Rahman, A. A. \& Muhammad, S. Z. 2016. Waqf in higher education: The experience of 'Wakaf Ilmu' in Universiti Putra Malaysia. pp. 226-233. In. S. Kayadibi \& S. Alimova (eds). Book of International Symposium on Waqf and Higher Education (ISWHE). Kuala Lumpur: Centre for Islamic Economics (CIE) Kulliyyah of Economics and Management Sciences (KENMS) International Islamic University Malaysia (IIUM).

Ali, Siti Zakiah \& Wahid, Hairunnizam 2014. Peranan dan kepentingan dana wakaf institusi pendidikan tinggi di Malaysia.https://www.ukm.my/fep/perkem/pdf/perkem2014/PERKEM_2014_2A4.pdf. Retrieved: 16th September 2018.

Alomair, M. 2018. Governance and Accountability in Corporate Waqf Institutions in Saudi Arabia. United Kingdom: University of London. 
Arshad, R., Zain, N. M., Urus, S. T. \& Chakir, A. 2018. Modelling maqasid waqf performance measures in waqf institutions. Global Journal Al-Thaqafah. Special Issue: 157-170. doi:10.7187/gjatsi2018-11

Azganin, H. 2019. Redevelopment of idle Waqf property through financial technology : Case of Malaysia. International Review of Entrepreneurial Finance. 2(1): 42-58.

Babacan, M. 2011. Economics of Philanthropic Institutions, Regulation and Governance in Turkey. Journal of Economic and Social Research. 13(12): 61-89.

Bruce, S. 2000. The supply-side model of religion: The Nordic and Baltic States. Journal for the Scientific Study of Religion. 39(1): 32-46.

Barney, S., Aurum, A. \& Wohlin, C. 2008. A product management challenge: Creating software product value through requirements selection. Journal of Systems Architecture. 54(6): 576593. doi:10.1016/j.sysarc.2007.12.004

Basri, H., Siti Nabiha, A. K. \& Majid, M. S. A. 2016. Accounting and accountability in religious organizations: An Islamic contemporary scholars' perspective. Gadjah Mada International Journal of Business. 18(2): 207-230. doi:10.22146/gamaijb.12574

Brignall, S. \& Modell, S. 2000. An institutional perspective on performance measurement and management in the "new public sector." Management Accounting Research. 11(3): 281-306. doi:10.1006/mare.2000.0136

Castillo-Montoya, M. 2016. Preparing for interview research: The interview protocol refinement framework. Qualitative Report. 21(5): 811-831.

Creswell, J. W. \& Creswell, J. D. 2018. Research designs qualitative, quantitative, and mixed methods approaches. Fast Facts to Loving your Research Project. California: SAGE Publications, Inc. doi:10.1891/9780826146373.0007

Cutt, J. \& Murray, V. 2003. Accountability and Effectiveness Evaluation in Non-Profit Organizations. London and New York Taylor \& Francis Group e-library.

Deloitte. 2020. Deloitte 's 2020: Global Blockchain Survey from Promise to Reality. https://www2.deloitte.com/content/dam/insights/us/articles/6608_2020-globalblockchain-survey/DI_CIR 2020 global blockchain survey.pdf. Retrived: 20th June 2020.

DiMaggio, P. \& Powell, W. W. 1983. The iron cage revisited: institutional isomorphism and collective rationality in organizational fields. American Sociological Review. 48: 147-160. doi:10.17323/1726-3247-2010-1-34-56

Ebrahim, A. 2003. Accountability in practice: mechanisms for NGOs. World Development 31(5): 813-829. doi:10.1016/S0305-750X(03)00014-7

Friedland, Roger \& Alford, Robert R. 1991. Bringing Society Back In: Symbols, Practices, and Institutional Contradictions. pp. 232-267. In Powell, W. W. \& DiMaggio, P. J. (eds). The New Institutionalism Organizational Analysis. Chicago, United States of America, University of Chicago Press.

Fuenfschilling, L. \& Truffer, B. 2014. The structuration of socio-technical regimes - Conceptual foundations from institutional theory. Research Policy. 43(4): 772-791. doi:10.1016/j.respol.2013.10.010

Gálvez Rodríguez, M. del M., Caba Pérez, M. del C. \& Godoy, M. L. 2012. Determining Factors in online transparency of NGOs: A Spanish case study. Voluntas. 23(3): 661-683. doi:10.1007/s11266-011-9229-x

Gazali, H. M. \& Che Ismail, C. M. H. 2019. A conceptual framework for cash waqf with blockchain in financing education for the Islamic religious school in Malaysia. $A L-I T Q \bar{A} N$. 3(1): 73-88.

Geels, F. W. 2004. From sectoral systems of innovation to socio-technical systems: Insights about dynamics and change from sociology and institutional theory. Research Policy. 33(6-7): 897-920. doi:10.1016/j.respol.2004.01.015

Ghazali, M. A.-I. \& Md. Sawari, S. S. 2014. Pengurusan waqf pendidikan di institusi perguruan tinggi Malaysia: satu sorortan literatur. International Journal of Islamic and Civilization Studies. 01: 35-44.

Habidin, N. F., Hussin, M. Y. M., Muhammad, F., Janudin, S. E. \& Fuzi, N. M. 2017. Critical Success 
factors, benefit, and auditing of waqf accounting. International Journal of Academic Research in Business and Social Sciences. 7(4): 1184-1189. doi:10.6007/ijarbss/v7-i4/2925

Hairul Suhaimi, N., Nur Suriana, A. \& Nor Suhaily, B. 2018. Exploring awqaf mutawalli's accounting and reporting practices: some preliminary Malaysian evidence. Pertanika Journal ofSocial Sciences \& Humanities. 26(4): 2583-2597.

Hamdan, N., Osman, A. Z. \& Rashid, H.-M. A. 2019. The stakeholders ecosystem of waqf institutions in Malaysia. Jurnal Syariah. 27(August): 281-300.

Haneef, M. A. 2016. Funding of higher education in Malaysia- The potential role of awqaf and endowments. pp. 20-25. In. S. Kayadibi \& S. Alimova (eds). Book of International Symposium on Waqf and Higher Education (ISWHE). Kuala Lumpur: Centre for Islamic Economics (CIE) Kulliyyah of Economics and Management Sciences (KENMS) International Islamic University Malaysia (IIUM).

Haron, A., Sahibuddin, S., Harun, M., Zakaria, N. H. \& Mahrin, M. N. 2013. The important role of people, process and technology during software project requirement. International Journal of Machine Learning and Computing. 3(1): 24-30. doi:10.7763/IJMLC.2013.V3.266

Hussin, R. \& Abdul Rashid, R. 2017. Diversifying income generation through waqf in public universities in Malaysia: efforts and challenges. IJASOS- International E-journal of Advances in Social Sciences. (February): 223-223. doi:10.18769/ijasos.309679

Ihsan, H. 2007. Towards the improvement of waqf accountability in Indonesia: A critical review of the Act No 41/2004 on Waqf. Jumal Akuntansi \& Manajemen. 2(2): 71-80.

Ihsan, H. \& Adnan, M. 2009. Waqf accounting and the construction of accountability. Humanomics. 27: 252-269.

Ihsan, Hidayatul \& Hj. Mohamed Ibrahim, S. H. 2011. WAQF accounting and management in Indonesian WAQF institutions: The cases of two WAQF foundations. Humanomics. 27(4): 252-269. doi:10.1108/08288661111181305

Ihsan, H. \& Septriani, Y. 2016. Accountability mechanisms for awqaf institutions: Lessons learnt from the history. Journal of King Abdul Aziz: Islamic Economics. 29(1): 41-54.

Iman, A. H. M. \& Mohammad, M. T. S. H. 2017. Waqf as a framework for entrepreneurship. Humanomics .33(4): 419-440. doi:10.1108/H-01-2017-0015

JAWHAR. 2008. Kompilasi Hukum Dan Fatwa Berkaitan Wakaf, Zakat, Haji \& Sumber Am 201. Malaysia. Jabatan Wakaf, Zakat dan Haji (JAWHAR), Jabatan Perdana Menteri.

JAWHAR. 2018. Panduan Pengurusan Wakaf Institusi Pendidikan. 1-248. Malaysia. Jabatan Wakaf, Zakat dan Haji (JAWHAR), Jabatan Perdana Menteri.

Johan, J., Yusof, A. M. \& Omar, I. 2016. Waqf for Financial sustainability of higher education in malaysia: issues and challenges. World Applied Sciences Journal. 34(9): 1167-1172. doi:10.5829/idosi.wasj.2016.34.9.15716

KPTM. 2016. Enhancing University Income Generation Endowment \& Waqf - UniTP Purple Book. Malaysia: Kementerian Pengajian Tinggi. doi:10.1017/CB09781107415324.004LHDN. 2020. Garis Panduan Permohonan Kelulusan Ketua Pengarah Hasil Dalam Negeri Di Bawah Subseksyen 44 (11D) Akta Cukai Pendapatan 1967 Bagi Wakaf. http://phl.hasil.gov.my/pdf/pdfam/GP_S44_11D_Wakaf_08102020.pdf. Retrieved: 6th March 2020.

Linn, L. A. \& Koo, M. B. 2016. Blockchain for health data and its potential use in health it and health care related research. https://www.healthit.gov/sites/default/files/11-74ablockchainforhealthcare.pdf. Retrieved: 26th February 2020.

Lounsbury, M. 2008. Institutional rationality and practice variation: New directions in the institutional analysis of practice. Accounting, Organizations and Society. 33(4-5): 349-361. doi:10.1016/j.aos.2007.04.001

Mansor, N. \& Jamil, A. 2018. Integrated waqf reporting system. International Journal of Accounting, Finance and Business. 2(6): 155-166.

Masruki, R. \& Shafii, Z. 2013. The development of Waqf accounting in enhancing accountability. Middle East Journal of Scientific Research. 13: 1-6. doi:10.5829/idosi.mejsr.2013.13.1873

Meyer, J. W., Rowan, B. ., Bergesen, A., Boli-Bennett, J., Deal, T., Freeman, J., Hirsch, P., et. al. 1977. 
Institutionalized organizations: formal structure as myth and ceremony. American Journal of Sociology. 83(2): 340-363. doi:10.1086/226550

Nahar, H. S. \& Yaacob, H. 2011. Accountability in the sacred context: The case of management, accounting and reporting of a Malaysian cash awqaf institution. Journal of Islamic Accounting and Business Research. 2(2): 87-113. doi:10.1108/17590811111170520

Nurul, K., Sikorski, J. J., Hadinoto, K. \& Kraft, M. 2018. Incorporating seller / buyer reputationbased system in blockchain-enabled emission trading application. Applied Energy. 209: 819. doi:10.1016/j.apenergy.2017.10.070

O'Donoghue, T. 2006. Planning your qualitative research project: An introduction to interpretivist research in education. Planning Your Qualitative Research Project: An Introduction to Interpretivist Research in Education. 1-224. doi:10.4324/9780203967720

Omar, Mustafa, M., Mohd Nizam, B., Yusof, S. A. \& Amin, R. M. 2016. Developing a framework for charitable giving from an Islamic perspective. pp. 26-34. In. S. Kayadibi \& S. Alimova (eds). Book of International Symposium on Waqf and Higher Education (ISWHE). Kuala Lumpur: Centre for Islamic Economics (CIE) Kulliyyah of Economics and Management Sciences (KENMS) International Islamic University Malaysia (IIUM).

Orlikowski, W. J. 1993. CASE tools as organizational change: investigating incremental and radical changes in systems development. MIS Quarterly: Management Information Systems. 17(3): 309-340. doi:10.4135/9781849209687.n11

Parent, M. M., Kristiansen, E., Skille, E. \& Hanstad, D. V. 2015. The sustainability of the Youth Olympic Games: Stakeholder networks and institutional perspectives. International Review for the Sociology of Sport. 50(3): 326-348. doi:10.1177/1012690213481467

Ramli, A., Mokhtar, M. \& Abdul Aziz, B. 2014. Revisiting the concept of development, disaster and safety management: the Quranic perspective. International Journal of Disaster Risk Reduction 9: 26-37. doi:10.1016/j.ijdrr.2014.03.006

Rana, T. \& Hoque, Z. 2020. Institutionalising multiple accountability logics in public services: insights from Australia. British Accounting Review. 52(4):1-13. doi:10.1016/j.bar.2020.100919

Saidon, R., Mat Rani, M. A., Muhamad, M. D. \& Ishak, A. H. 2019. Examining the practice of waqfbased education in Indonesia. International Journal of Civil Engineering and Technology (IJCIET). 10(2): 814-819.

Sanzo-Pérez, M. J., Rey-Garcia, M. \& Álvarez-González, L. I. 2017. The drivers of voluntary transparency in nonprofits: professionalization and partnerships with firms as determinants. Voluntas. 28(4): 1595-1621. doi:10.1007/s11266-017-9882-9

Selangor. 2015. Enakmen 15 Tahun 2015 Enakmen Wakaf (Negeri Selangor) 2015. http://www2.esyariah.gov.my/esyariah/mal/portalv1/enakmen2011/State_Enact_Ori.nsf /f831ccddd195843f48256fc600141e84/95713fbe180e443448257f6f000e4f08?0penDoc ument. Retrieved: 2nd July 2020.

Singh, S., Tuli, S., Xu, M., Singh, I., Vijay, K., Lindsay, D., Tuli, S., et. al. 2019. Internet of Things transformative effects of IoT, blockchain and artificial intelligence on cloud computing: evolution, vision, trends and open challenges. Internet of Things. 8(October): 1-30. doi:10.1016/j.iot.2019.100118

Siraj, S. A. 2012. An Empirical Investigation into the Accounting, Accountability and Effectiveness of Waqf Management in the State Islamic Religious Councils (SRICs) in Malaysia. United Kingdom: Cardiff University.

Siswantoro, D., Rosdiana, H. \& Fathurahman, H. 2018. Reconstructing accountability of the cash waqf (endowment) institution in Indonesia. Managerial Finance. 44(5): 624-644. doi:10.1108/MF-05-2017-0188

Siti Umairah, A. H. \& Siti Mashitoh, M. 2016. Aplikasi prinsip berkekalan wakaf di ipt terpilih: perpektif perundangan. Journal of Shariah Law Research. 1(2): 229-250.

Strauss, A. \& Corbin, J. 1998. Basics of Qualitative Research: Techniques and Procedures for developing Grounded Theory. United States of America: SAGE Publications, Inc. 
doi:10.1177/1350507600314007

Suhaili, N. A. 2016. A way forward for reviving waqf in high education through collaboration. pp. 204-210. In. S. Kayadibi \& S. Alimova (eds). Book of International Symposium on Waqf and Higher Education (ISWHE). Kuala Lumpur: Centre for Islamic Economics (CIE) Kulliyyah of Economics and Management Sciences (KENMS) International Islamic University Malaysia (IIUM).

Syakir, M., Taib, M., Mujani, W. K., Rozali, E. A. \& Khalid, K. A. 2017. Perkembangan Wakaf pendidikan tinggi di Malaysia. International Journal of West Asian Studies. 9(1): 82-92. doi:10.22583/ijwas.2017.09.01.07

Taib, M. S. M., Mujani, W. K., Ya’akub, N. I., Rozali, E. A., Talib@Khalid, K. A., Izwan, M. K. \& Hussin, R. 2016. The scenario of waqf higher education in Malaysia and the responsibility of Malaysian Government. pp. 195-203. In. S. Kayadibi \& S. Alimova (eds). Book of International Symposium on Waqf and Higher Education (ISWHE). Kuala Lumpur: Centre for Islamic Economics (CIE) Kulliyyah of Economics and Management Sciences (KENMS) International Islamic University Malaysia (IIUM). ,

The World Bank Group, I. \& I. 2019. Report on Maximizing Social Impact through Waqf Solutions. Malaysia: The World Bank Group \& International Centre for Education in Islamic Finance \& International Shariah Research Academy for Islamic Finance.

Thornton, P. H. \& Ocasio, W. 1999. Institutional logics and the historical contingency of power in organizations : executive succession in the higher education publishing industry , 1958 1990. American Journal of Sociology. 105(3): 801-843.

Vaast, E. \& Walsham, G. 2005. Representations and actions: the transformation of work practices with IT use. Information and Organization 15(1): 65-89. doi:10.1016/j.infoandorg.2004.10.001

Walker, M. A. \& Moore, J. D. 1997. Empirical studies in discourse. Computational Linguistics. 22(2): 1-12.

Walsham, G. 1995. Interpretive case studies in IS research. European Journal of Information Systems. (4): 74-81.

Williams, S. P., Hardy, C. A. \& Holgate, J. A. 2013. Information security governance practices in critical infrastructure organizations: A socio-technical and institutional logic perspective. Electronic Markets. 23(4): 341-354. doi:10.1007/s12525-013-0137-3

Yin, R. K. 2003. Case Study Research Design and Methods. London and New Delhi: SAGE Publications.

Yin, R. K. 2011. Qualitative Research from Start to Finish. New York: The Guilford Press.

Zhang, Y., Zhang, J. \& Chen, J. 2013. Critical success factors in IT service management implementation: People, process, and technology perspectives. Proceedings of International Conference on Service Science, ICSS. (April 2013): 64-68. doi:10.1109/ICSS.2013.38

Zulaikha, S. \& Arif Rusmita, S. 2018. Blockchain for Waqf Management. KnE Social Sciences 3(10): 1152-1158. doi:10.18502/kss.v3i10.3457 